\title{
Islet Cell Function in Gold Thioglucose-Induced Obesity in Mice
}

\author{
I.D. Caterson* and K. W. Taylor** \\ Department of Biochemistry, University of Sydney, Sydney, Australia
}

\begin{abstract}
Summary. Blood insulin, blood glucose and the biosynthesis and release of insulin have been studied in mice made obese with a single injection of gold thioglucose. In such mice, blood glucose levels were normal, though serum insulin rose in parallel with the development of obesity. When compared with controls, insulin secretion and synthesis were increased in isolated islets of Langerhans from obese mice, over a wide range of glucose concentrations. However, in obese animals, insulin biosynthesis was augmented above control levels at $2 \mathrm{mmol} / 1$ glucose, whilst the increase in insulin secretion accompanying obesity only became evident at glucose concen-
\end{abstract}

trations $>5 \mathrm{mmol} / \mathrm{l}$. After $2 \mathrm{~min}$ incubation, cyclic AMP rose more in islets from obese mice than in controls, though cyclic AMP levels did not significantly differ in either group after 10 min incubation with glucose. Glucose oxidation was also increased in islets of Langerhans from obese mice. It seems possible that changes in glucose oxidation, as well as in cyclic AMP levels, contribute to the alteration in the $\mathrm{B}$ cell response in this type of obesity.

Key words: Pancreas, mice, gold thioglucose, islet metabolism, insulin synthesis and release.
Most available animal models of obesity are deficient in some aspects when compared with human obesity. The genetic forms of obesity (e.g. $o b / o b$ and $d b / d b$ mice) show alterations in peripheral metabolism [1] or in insulin secretion [2] which antedate the obesity, whilst animals with obesity caused by surgical or electrolytic lesions of the hypothalamus exhibit an early rise in serum insulin.

Gold thioglucose (1-aurothioglucose) is known to cause both an hypothalamic infarct and obesity in mice [3]. It is presumed to raise serum insulin [4], though endocrine aspects of this syndrome have not been described in detail. Gold thioglucose itself causes transient increases in insulin secretion from isolated islets of Langerhans but appears to have no permanent effect [5]. The syndrome of obesity caused by this drug is a good one in which to study the long-term control of insulin secretion and synthesis in animals which were normal before a single injection of this compound. Moreover, to date, there have been only sporadic investigations on the secretory activity of islets from mice with this form of obesity [6].

* Present address: Department of Medicine, University of Sydney, NSW 2006, Australia

** Present address: Department of Biochemistry, London Hospital Medical College, Turner St., London E1 2AD, UK
Several mechanisms have been suggested to explain long-term alterations in the control of insulin secretion and synthesis. In pregnancy and starvation, changes in islet cyclic AMP levels seem to play a role. In pregnancy, with increased insulin secretion and synthesis, both cyclic AMP levels and adenylate cyclase activity are increased [7-9], whilst in starvation (where there is a reduced insulin response to a glucose challenge) the reverse is found [10-12].

There is also the possibility that changes in glucose metabolism and oxidation within the B cells of islets may be important in initiating the changes in insulin secretion and synthesis [13]. In addition, therefore, cyclic AMP accumulation and rates of glucose oxidation have been measured in islets from mice made obese with gold thioglucose treatment.

\section{Materials and Methods}

All mice used were of the inbred CBA/T6 strain provided by the Blackburn Animal House, Department of Immunology, University of Sydney, NSW, Australia, and were fed Rat and Mouse Kubes provided by Allied Feeds, Rhodes, NSW, Australia. The composition of this food was as follows:- crude protein (minimum) $23.0 \%$, crude fat $5.0 \%$, crude fibre (maximum) $6.0 \%$, carbohydrate $65 \%$, salt $0.8 \%$ with no urea or fluoride added. ${ }^{125} \mathrm{I}$ and $\mathrm{L}\left[4,5{ }^{3} \mathrm{H}\right]$ leucine and $\mathrm{D}-\left(\mathrm{U} \cdot{ }^{14} \mathrm{C}\right)$ 
glucose were supplied by the Radiochemical Centre, Amersham, UK, and ${ }^{125}$ I succinyl cyclic AMP was supplied by the New England $\mathrm{Nu}-$ clear Corporation, Boston, Mass, USA.

Mice were injected IP with a single injection of gold thioglucose ( $0.35 \mathrm{mg} / \mathrm{g}$ body weight) and allowed food and water ad libitum; a further gold thioglucose-injected group were allowed, each day, only the amount of food eaten by pair fed saline-injected controls.

Glucose was assayed by the glucose oxidase method of Bergemeyer and Bernt [14] using ' 2 azino di ( 3 ethyl benzthiazoline)-6-sulphonate. Insulin was measured by radioimmunoassay using a double antibody method.

Islets were isolated from fed mice by the collagenase digestion technique of Howell and Taylor [15] and incubated in a buffered bicarbonate medium.

Five islets of Langerhans were incubated in $1.0 \mathrm{ml}$ buffered bicarbonate medium containing $0.1 \%$ bovine serum albumin and varying concentrations of glucose. The islets were incubated for $1 \mathrm{~h}$ at $37^{\circ} \mathrm{C}$. At the end of this time, the incubation vial was centrifuged at $1,500 \times g$ for 2 min and the medium removed for insulin assay. The islets were then sonicated in $50 \mu \mathrm{ll} 0.01 \mathrm{~mol} / 1 \mathrm{HCl}$ at 25 watts for $12 \mathrm{~s}$ with a Branson Sonifier Model B-15P. This sonicate was then centrifuged at $3,000 \times g$ for $5 \mathrm{~min}$ and was assayed for insulin content.

Insulin synthesis was estimated in 15 islets of Langerhans incubated for $1 \mathrm{~h}$ in $200 \mu \mathrm{l}$ buffered bicarbonate medium containing $0.1 \mathrm{mCi}$ $\mathrm{L}\left[4,5{ }^{3} \mathrm{H}\right]$ leucine and varying concentrations of glucose $(2-20 \mathrm{~mol} / \mathrm{l})$. Radioactive insulin was purified by the method of Berne [16]. The vials were counted in an Isocap Liquid Scintillation Counter for $10 \mathrm{~min}$ (or minimum of 5,000 counts). The results are expressed as radioactivity incorporated into insulin. No attempt was made in these experiments to differentiate between radioactivity incorporated into insulin or into proinsulin.

For the determination of cyclic AMP content of islets of Langerhans ten islets of approximately equal size were pre-incubated for $15 \mathrm{~min}$ at $37^{\circ} \mathrm{C}$ in a buffered bicarbonate medium, containing $5 \mathrm{mmol} / 1$ glucose. The vials were then centrifuged, the medium removed and $15 \mu \mathrm{l}$ of fresh medium added. This fresh medium contained varying concentrations of glucose, ranging from $2-20 \mathrm{mmol} / \mathrm{l}$. After 2 or $10 \mathrm{~min}$ incubation at $37^{\circ} \mathrm{C}$, the incubation reactions were stopped by the addition of $35 \mu \mathrm{l}$ of ice-cold $0.1 \mathrm{~mol} / 1 \mathrm{HCl}$. The islets were then sonicated and the sonicate was centrifuged as before. Aliquots of the supernatant were taken to measure cyclic AMP and insulin.

Cyclic AMP was measured by radioimmunoassay, using the method described by Steiner et al. [17].

Glucose oxidation in the islets was measured by a modification of a method described by Campbell and Taylor [18]. Fifteen islets of Langerhans in suitable small volumes of buffered bicarbonate medium containing either $0.05 \mu \mathrm{mol}$ or $0.2 \mu \mathrm{mol} \mathrm{D}-\left(\mathrm{U}-{ }^{14} \mathrm{C}\right)$ glucose $(5$ or $20 \mathrm{mmol} / 1$ concentration) were incubated in a small centrifuge tube for $90 \mathrm{~min}$ at $37^{\circ} \mathrm{C}$. The islets remaining in the incubation medium were sonicated as before and the total insulin in the sonicate measured.

\section{Islet Insulin: DNA Ratio}

The method used for the measurement of DNA in islets was that of Hinegardner [19] as described by Green and Taylor [20]. The reagent used was 3,5 diaminobenzoic acid dihydrochloride $(0.45 \mathrm{~g} / \mathrm{ml}$ water $)$. Standard quantities of DNA (5-2500 ng) were prepared using calf thymus DNA in water $(1 \mathrm{mg} / \mathrm{ml})$. Total DNA was measured in 5-25 islets. At the same time, the total insulin in five islets was measured using the methods described earlier. The insulin: DNA ratio could then be calculated.

\section{Experimental Design}

Three fed groups of mice of the same age were used for these experiments. These were: (1) a saline-injected control group, (2) a gold thioglucose-injected group which were not permitted to become obese (this was achieved by feeding this group of mice only the amount of chow which a pair fed group of saline injected mice had eaten) and (3) a gold thioglucose-injected group which became obese. Comparisons were made between two or more of these groups.

\section{Expression of Values in Relation to Islet Metabolism}

It is well known that the islets of Langerhans in obesity in mice are considerably larger than those of control animals, and that they contain more insulin [21]. This is probably due to increased numbers of $B$ cells, as in pregnancy [20]. However, in our experiments the insulin: DNA ratio did not ehange in gold thioglucose obese animals when compared with that in normal animals. The ratio derived from five obese animals was $0.071 \pm 0.020$ and was $0.069 \pm 0.007$ for six saline-injected control animals (mean \pm SEM). To avoid the problem of differing islet size and cellularity, results on islets have been calculated in terms of insulin content.

\section{Results}

When injected intraperitoneally with a single dose of gold thioglucose, CBA/T6 mice became obese within 6 weeks. Mortality among these mice was $12.5 \%$. Obese animals are defined as those which had a body weight $30 \%$ above that of controls by 6 weeks after gold thioglucose injection. The hyperphagia induced by the injection of gold thioglucose was maintained after the initial rapid weight gain had ceased. (At week 6 after injection, control mice ate $3.8 \pm 0.1 \mathrm{~g} /$ day, and animals injected with $0.3 \mathrm{mg}$ gold thioglucose ate $4.9 \pm 0.4 \mathrm{~g} /$ day.)

In this strain of mice, there was no difference in blood glucose levels between the gold thioglucose-treated group and the saline control group (Table 1). On the other hand, though there was some variation serum insulin levels were generally elevated in the gold thioglucose-treated group. This is particularly the case at 6 weeks treatment. In this and subsequent tables each observation represents results obtained from a single animal.

There was no difference in glucose-stimulated insulin secretion from islets isolated from saline-injected control mice, or mice injected with gold thioglucose and not permitted to become obese (Table 2). These mice were of the same age and weight and were pair fed. There appeared, therefore, to be no effect of a single dose of gold thioglucose on insulin secretion.

Table 2 shows rates of insulin secretion from isolated islets of obese and control mice. There was no difference in the basal secretion of insulin (i.e. that induced by glucose concentrations of $5 \mathrm{mmol} / 1$ or less). However, there was a marked increase in secretion at glucose concentrations above basal.

The rate of insulin synthesis in isolated islets of Langerhans from the three groups of CBA/T6 mice is shown in Table 3. Islets from obese mice exhibited greatly increased levels of insulin synthesis when compared with both sets of controls. The increase in insulin synthesis in obese islets approximately parallels the in- 
Table 1. Blood glucose and serum insulin levels in mice injected with gold thioglucose $(0.35 \mathrm{mg} / \mathrm{g})$ at weeks $1-6$ during the phase of weight gain

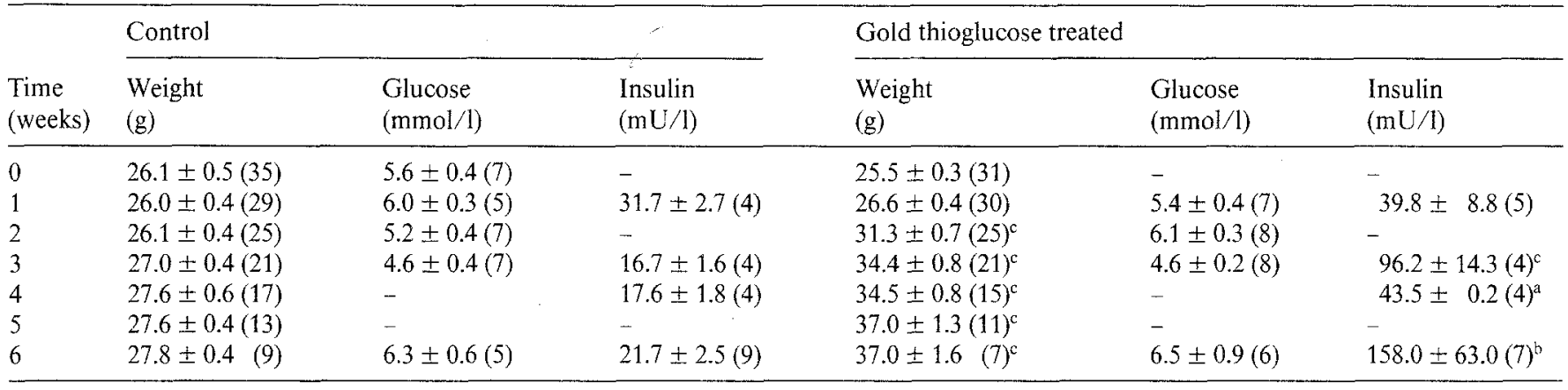

All results shown as mean \pm SEM with number of observations in parentheses. For comparison with controls: ${ }^{\mathrm{a}} p<0.05, \quad{ }^{\mathrm{b}} p<0.02,{ }^{\mathrm{c}} p<0.01$, using Student's t-test

Table 2. Insulin secretion from islets of Langerhans isolated from obese and control groups of mice

\begin{tabular}{|c|c|c|c|}
\hline \multirow[b]{2}{*}{$\begin{array}{l}\text { Glucose } \\
\text { concen- } \\
\text { tration } \\
(\mathrm{mmol} / \mathrm{l})\end{array}$} & \multicolumn{3}{|c|}{$\begin{array}{l}\text { Insulin secretion ( } \mu \mathrm{U} \text { insulin secreted: } \mu \mathrm{g} \text { islet } \\
\left.\text { insulin }{ }^{-1} \cdot \min ^{-1}\right)\end{array}$} \\
\hline & Saline control & $\begin{array}{l}\text { Gold } \\
\text { thioglucose } \\
\text { non-obese } \\
\text { control }\end{array}$ & $\begin{array}{l}\text { Gold } \\
\text { thioglucose } \\
\text { obese }\end{array}$ \\
\hline 0 & $5.8 \pm 0.6(22)$ & - & $7.1 \pm 1.2(16)$ \\
\hline 2 & $8.0 \pm 0.6(21)$ & $6.8 \pm 1.4(5)$ & $6.3 \pm 1.2(10)$ \\
\hline 5 & $8.1 \pm 0.6(24)$ & $8.7 \pm 0.7(6)$ & $7.9 \pm 0.7(12)$ \\
\hline 10 & $10.2 \pm 0.6(23)$ & $12.6 \pm 1.6(7)^{\mathrm{b}}$ & $23.0 \pm 3.1(12)^{\mathrm{a}}$ \\
\hline 15 & $13.8 \pm 0.7(25)$ & $16.4 \pm 1.1(5)^{b}$ & $27.5 \pm 2.4(13)^{\mathrm{a}}$ \\
\hline 20 & $15.3 \pm 0.9(21)$ & $18.1 \pm 1.3(7)^{b}$ & $33.9 \pm 3.9(13)^{b}$ \\
\hline
\end{tabular}

All results expressed as mean \pm SEM with number of observations in parentheses. For obese mice compared with saline-injected control mice: " $p<0.001$; for obese mice compared with gold thioglucose non-obese controls ${ }^{\mathrm{b}} p<0.01$, using Student's t-test

Table 3. Insulin biosynthesis in isolated islets of Langerhans from obese and control mice

\begin{tabular}{llll}
\hline \multicolumn{4}{c}{$\begin{array}{l}\text { Insulin biosynthesis (dpm incorporated } \cdot \mathrm{ng} \\
\text { insulin }\end{array}$} \\
\cline { 2 - 4 } $\begin{array}{l}\text { Glucose } \\
\text { concen- }\end{array}$ & Saline control & $\begin{array}{l}\text { Gold } \\
\text { thioglucose } \\
\text { tration } \\
\text { non-obese } \\
\text { control }\end{array}$ & $\begin{array}{l}\text { Gold } \\
\text { thioglucose } \\
\text { obese }\end{array}$ \\
\hline 2 & & & $10.1 \pm 2.7(8)^{b}$ \\
5 & $1.5 \pm 0.2(8)$ & - & $9.7 \pm 1.3(13)^{\mathrm{c}}$ \\
10 & $5.3 \pm 0.9(13)$ & $6.2 \pm 1.2(10)$ & $21.4 \pm 4.7(8)^{\mathrm{c}}$ \\
15 & $7.5 \pm 1.8(8)$ & - & $26.5 \pm 1.9(7)^{\mathrm{a}}$ \\
20 & $9.0 \pm 1.3(10)$ & - & $29.1 \pm 2.6(13)^{\mathrm{a}}$ \\
\hline
\end{tabular}

All results given as mean \pm SEM with number of observations in parentheses. For values compared with saline injected control mice: a $p<0.001 ;{ }^{\mathrm{b}} p<0.01 ;{ }^{\mathrm{c}} p<0.02$, using Student's t-test

crease in insulin secretion at higher glucose levels. However, at 2 and $5 \mathrm{mmol} / 1$ glucose, obese mice exhibit marked increases in the rate of insulin synthesis in comparison with saline-injected controls.

The cyclic AMP levels in islets isolated from control and obese mice are shown in Table 4 . After 10 min incubation there was a rise in cyclic AMP levels with
Table 4. Cyclic AMP accumulation in isolated islets of Langerhans from control and obese mice after $2 \mathrm{~min}$ and $10 \mathrm{~min}$ of incubation

\begin{tabular}{llll}
\hline $\begin{array}{lll}\text { Incubation } \\
\text { time }\end{array}$ & $\begin{array}{l}\text { Glucose } \\
\text { concen- } \\
\text { tration } \\
\text { (mmol/1) }\end{array}$ & \multicolumn{2}{l}{ Cyclic AMP content (fmol/ng insulin) } \\
\cline { 3 - 4 } & 5 & $0.20 \pm 0.05(15)$ & $0.60 \pm 0.07(9)^{\mathrm{a}}$ \\
\hline $2 \mathrm{~min}$ & 5 & $0.30 \pm 0.04(9)$ & $0.51 \pm 0.06(9)^{\mathrm{b}}$ \\
& 10 & $0.39 \pm 0.06(18)$ & $0.75 \pm 0.14(6)^{\mathrm{c}}$ \\
& 20 & $0.26 \pm 0.06(10)$ & $0.39 \pm 0.06(11)$ \\
$10 \mathrm{~min}$ & 0 & $0.31 \pm 0.07(14)$ & $0.34 \pm 0.03(12)$ \\
& 5 & $0.38 \pm 0.05(9)$ & $0.46 \pm 0.04(7)$ \\
& 7.5 & $0.44 \pm 0.07(18)$ & $0.43 \pm 0.02(17)$ \\
& 10 & $0.49 \pm 0.06(16)$ & $0.62 \pm 0.08(14)$ \\
\hline
\end{tabular}

Values given are mean \pm SEM with number of observations in parentheses. For values compared with control mice:

${ }^{a} p<0.001 ;{ }^{b} p<0.01 ;{ }^{c} p<0.05$, using Student's t-test

Table 5. Glucose oxidation in isolated islets of Langerhans from control and obese mice

\begin{tabular}{|c|c|c|c|}
\hline \multirow{2}{*}{$\begin{array}{l}\text { Glucose } \\
\text { concen- } \\
\text { tration } \\
(\text { mmol/l) }\end{array}$} & \multicolumn{3}{|c|}{ Glucose oxidation (pmol $\cdot \mathrm{ng}$ insulin ${ }^{-1} \cdot 90 \mathrm{~min}^{-1}$ ) } \\
\hline & Saline control & $\begin{array}{l}\text { Gold thioglu- } \\
\text { cose injected } \\
\text { non-obese } \\
\text { control }\end{array}$ & $\begin{array}{l}\text { Gold } \\
\text { thioglucose } \\
\text { obese }\end{array}$ \\
\hline 5 & $3.4 \pm 0.5(7)$ & $6.4 \pm 0.5(4)$ & $25.5 \pm 1.6(7)^{\mathrm{a}}$ \\
\hline 20 & $21.2 \pm 3.8(9)$ & $24.4 \pm 4.2(5)$ & $99.2 \pm 14.4(8)^{a}$ \\
\hline
\end{tabular}

Values given are mean \pm SEM with number of observations in parentheses. For values compared with controls: ${ }^{a} p<0.001$, using Student's t-test

increasing glucose concentration in both obese and control animals, which was similar in magnitude. However, after only 2 min of incubation, islets from obese mice showed a greater rise in islet cyclic AMP content than the control islets incubated at various glucose concentrations.

When glucose oxidation in isolated islets of Langerhans was measured, there was a greatly increased rate of oxidation at glucose concentrations of both 5 and $20 \mathrm{mmol} / 1$ in islets from obese mice (Table 5). 


\section{Discussion}

It is generally accepted that mice made obese with gold thioglucose do not become diabetic, though under conditions of stress some may do so [22-24]. These CBA/T6 mice have normal blood glucose levels and are not diabetic (Table 1).

Serum insulin levels in gold thioglucose obesity have been reported to be elevated $[22,24]$ though Malaisse et al. [6], in a paper demonstrating increased insulin secretion from pancreatic slices, reported normal serum insulin levels in this syndrome. In the current study, serum insulin levels rose as the animals became obese. This may be due to the hyperphagia and increased caloric intake, to the obesity itself or to alterations in peripheral metabolism induced by obesity.

In earlier experiments gold thioglucose has been shown to have a transient potentiating effect on insulin secretion due to glucose [5]. However, in the experiments reported here, there is no evidence for long-term changes affecting the insulin secretory responses of islets and it may be assumed that this is a valid model for studying obesity. Furthermore, islets from gold thioglucose-treated mice, not permitted to become obese, had normal insulin secretion and synthesis patterns. Clearly gold thioglucose, in the absence of obesity, does not permanently affect islet function.

Insulin secretion from the isolated islets of control mice shows the expected increase with increasing glucose concentration. It is interesting to note that the increased secretion from islets of obese animals only became evident at glucose concentrations above $5 \mathrm{mmol} / \mathrm{l}$. These observations are consistent with the elevated serum levels of insulin found in obesity and the increased insulin secretion found both with pancreatic slices and isolated islets from obese mice. In comparison with controls, islets isolated from obese mice showed an increased incorporation of $\left[{ }^{3} \mathrm{H}\right]$-leucine into insulin at all glucose concentrations including basal levels $(2$ and $5 \mathrm{mmol} / \mathrm{l})$. This indicates an increase in insulin synthesis in obesity. Moreover, insulin synthesis was increased at basal glucose levels while insulin secretion was not.

After 2 min incubation, islets from obese mice showed a rise in cyclic AMP content, though this had disappeared at $10 \mathrm{~min}$. There is considerable evidence that changes in the cyclic AMP content of islets, as well as changes in glucose oxidation, are associated with altered secretory or biosynthetic function [25]. This is well shown in islets from pregnant rats where both glucose oxidation rates and cyclic AMP content are increased $[9,20,26]$. It is generally supposed that rates of glucose oxidation are intimately concerned with the rates of insulin secretion, with alterations in the ratio $\mathrm{NAD}(\mathrm{P})$ : $\mathrm{NAD}(\mathrm{P}) \mathrm{H}$ being perhaps especially significant. How such ratios may be affected in the long term remains open to speculation.

The role of cyclic AMP in relation to biosynthesis and release also remains controversial. However, it seems at least likely that increases in islet cyclic AMP may potentiate the effects of glucose [8]. Even though there are transient changes in cyclic AMP content in islets of obese mice, these might still be important in initiating changes in insulin secretion and biosynthesis.

In addition, calcium ionic fluxes have not been measured in these experiments. We cannot exlude the possibility that changes in calcium transport (by, for example, influencing cyclic AMP) might play a role in changing islet metabolism in this type of obesity. It may well be that the increase in glucose oxidation rates as well as changes in islet cyclic AMP can together underlie the important alterations of islet function already noted. Perhaps no single metabolic factor is involved in producing such changes.

Alternatively, enterohormones [27] may affect islet sensitivity to glucose, particularly through the availability of extra carbohydrate in the gastrointestinal tract. Increased release of such hormones could well modify islet metabolism. Whatever the mechanism, it is clear that this form of obesity produces major long term adjustments in islet function, without in this instance leading to diabetes.

Acknowledgements. I. D. Caterson was the recipient of a Medical Postgraduate Research Fellowship from the National Health and Medical Research Council of Australia. We also wish to record our profound thanks to Professor C. Hellerström of Uppsala, Sweden, for helpful advice in relation to some aspects of the work.

\section{References}

1. Trayhurn P, Thurlby PL, James WPT (1977) Thermogenic defect in pre-obese ob/ob mice. Nature 266:60-61

2. Coleman DL, Hummel EP (1976) Hyperinsulinaemia in preweaning diabetes $(\mathrm{db} / \mathrm{db})$ mice. Diabetologia 10:607-610

3. Marshall NB, Barrnett RJ, Meyer J (1955) Hypothalamic lesions in gold thioglucose-injected mice. Proc Soc Exp Biol Med 90: 240-244

4. Bray GA, York DA (1979) Hypothalamic and genetic obesity in experimental animals: an autonomic and endocrine hypothesis. Physiol Rev 59: 719-809

5. Caterson ID, Taylor KW (1979) Direct effects of gold thioglucose on insulin secretion by isolated rat islets of Langerhans. FEBS Lett 98: 351-354

6. Malaisse WJ, Malaisse-Lagae F, Coleman DL (1968) Insulin secretion in experimental obesity. Metabolism 17:802-807

7. Green IC, Howell SL, Montague W, Taylor KW (1973) Regulation of insulin release from isolated islets of Langerhans of the rat in pregnancy. The role of adenosine $3^{\prime} 5^{\prime}$ cyclic monophosphate. Biochem J 134: 481-487

8. Bone AJ, Howell SL (1977) Alterations in regulation of insulin biosynthesis in pregnancy and starvation studied in isolated rat islets of Langerhans. Biochem J 166: 501-507

9. Green IC, Perrin D, Howell SL (1978) Insulin release in isolated islets of Langerhans in pregnant rats. Relationship between glucose metabolism and cyclic AMP. Horm Metab Res 10: 32-35

10. Buchanan KD, Vance JE, Williams RH (1969) The effect of starvation on insulin and glucagon release from isolated islets of Langerhans of the rat. Metabolism 18: 155-162

11. Selawry H, Gutman R, Fink G, Recant L (1977) The effect of starvation on tissue adenosine-3' $5^{\prime}$ monophosphate levels. Biochem Biophys Res Comm 51: 198-204 
12. Wolters GHJ, Konijnendijk W, Bouman PR (1977) Effects of fasting on insulin secretion, islet glucose metabolism and the cyclic adenosine $3^{\prime} 5^{\prime}$ monophosphate content of rat pancreatic islets in vitro. Diabetes 26: 530-537

13. Ashcroft SJH (1980) Glucoreceptor mechanisms and the control of insulin release and biosynthesis. Diabetologia 18: 5-15

14. Bergemeyer HU, Bernt E (1974) D glucose - determination with glucose oxidase and peroxidase. In: Bergemeyer HU (ed) Methods in enzymic analysis, 2nd ed. Academic Press, New York, pp 1205-1215

15. Howell SL, Taylor KW (1968) Potassium ions and the secretion of insulin by islets of Langerhans incubated in vitro. Biochem $\mathrm{J} 108$ : 17-24

16. Berne C (1975) Anti-insulin serum coupled to Sepharose-4B as a tool for the investigation of insulin biosynthesis in the B cells of obese hyperglycaemic mice. Endocrinology 97: 1241-1247

17. Steiner AL, Parker CW, Kipnis DM (1972) Radioimmunoassay for cyclic nucleotides. I. Preparation of antibodies and iodinated cyclic nucleotides. J Biol Chem 247: 1106-1113

18. Campbell IL, Taylor KW (1982) Effects of adenosine 2-deoxyadenosine and $\mathrm{N}^{6}$-phenylisopropyladenosine on rat islet function and metabolism. Biochem $\mathrm{J}$ (in press)

19. Hinegardner RT (1971) An improved fluorometric assay for DNA. Anal Biochem 39: 197-201

20. Green IC, Taylor KW (1972) Effects of pregnancy in the rat on the size and insulin secretory response of the islets of Langerhans. $J$ Endocrinol 54: 317-325

21. Peterson B, Hellman B (1962) The pancreatic islet tissue in mice with obesity induced by gold thioglucose. Acta Pathol Microbiol Scand 55: $401-405$
22. Katsuki S, Hirata Y, Horino M, Ito M, Ishimoto M, Makino N, Hososako A (1962) Obesity and hyperglycaemia induced in mice by gold thioglucose. Diabetes 11:209-215

23. Matsuo T, Shino A (1972) Induction of diabetic alterations by gold thioglucose obesity in KK, ICR and C57B1 mice. Diabetologia 8: $391-397$

24. Le Marchand Y, Freychet P, Jeanrenaud B (1978) Longitudinal study on the establishment of insulin resistance by hypothalamic obese mice. Endocrinology 102: 74-85

25. Hedeskov CJ (1980) Mechanism of glucose induced insulin secretion. Physiol Rev 60: 442-509

26. Bone AJ, Taylor KW (1976) Metabolic adaptation to pregnancy shown by increased biosynthesis of insulin in islets of Langerhans isolated from pregnant rats. Nature 262: 501-502

27. Bloom SR, Polak JM (1980) The alimentary endocrine system. In: Sircus W, Smith AN (eds) Scientific foundations of gastroenterology. Heineman, London, pp 101-122

Received: 22 October 1981

and in revised form: 27 April 1982

Professor K. W. Taylor

Department of Biochemistry

London Hospital Medical College

Turner Street

London E1 2AD, UK 